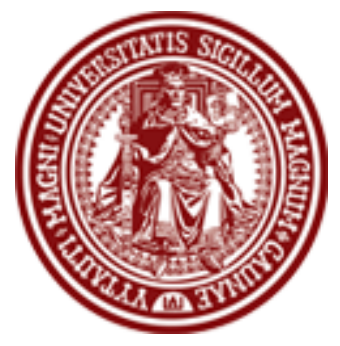

BALTIC JOURNAL OF LAW \& POLITICS

VOLUME 6, NUMBER 2 (2013)

ISSN 2029-0454

http://www.degruyter.com/view/j/bjlp

Cit.: Baltic Journal of Law \& Politics 6:2 (2013): 149-166

DOI: $10.2478 /$ bjlp-2013-0015

BOOK REVIEWS:

THE POLITICS OF ENCOUNTER: URBAN THEORY AND PROTEST

UNDER PLANETARY URBANIZATION; ELECTIONS TO THE

EUROPEAN PARLIAMENT AS A CHALLENGE FOR DEMOCRACY;

AND TRANSFORMATIONS IN CENTRAL EUROPE BETWEEN 1989

AND 2012: GEOPOLITICAL, CULTURAL, AND SOCIOECONOMIC

SHIFTS

\author{
Arnoldas Stramskas \\ Doctoral Student \\ Vytautas Magnus University Faculty of Political Science and Diplomacy \\ (Lithuania) \\ Contact information \\ Address: Gedimino str. 44, LT-44240 Kaunas, Lithuania \\ Phone: +370 37206709 \\ E-mail address: a.stramskas@pmdf.vdu.It
}

Tanel Kerikmäe

Professor

Tallinn University of Technology Tallinn Law School (Estonia)

Contact information

Address: Ehitajate tee 5, 19086 Tallinn, Estonia

Phone: +3726202430

E-mail address: tanel.kerikmae@ttu.ee

\title{
Andrius Martinkus
}

Assistant Professor; Dr.

Vilnius University Kaunas Faculty of Humanities (Lithuania)

Contact information

Address: Muitines str. 12, LT-44280 Kaunas, Lithuania

Phone: +370 37202627

E-mail address: andriusmartinkus@yahoo.com 


\section{ABSTRACT}

This article contains three book reviews. The reviewed books are: The Politics of Encounter: Urban Theory and Protest under Planetary Urbanization (2013) by Andy Merrifield; Elections to the European Parliament as a Challenge for Democracy, European Integration and Democracy Series Vol. 2 (2013), Eds. Elżbieta Kużelewska and Dariusz Kloza; and, Transformations in Central Europe between 1989 and 2012: Geopolitical, Cultural, and Socioeconomic Shifts (2012) by Tomas Kavaliauskas.

\section{KEYWORDS}

Andy Merrifield; Elżbieta Kużelewska; Dariusz Kloza; Tomas Kavaliauskas 


\section{ANDY MERRIFIELD. THE POLITICS OF ENCOUNTER: URBAN THEORY AND PROTEST UNDER PLANETARY URBANIZATION. THE UNIVERSITY OF GEORGIA PRESS: ATHENS AND LONDON, 2013.}

"At every moment of the encounter, I discover in the other another myself: You like this? So do I! You don't like that? Neither do I!" This quote by Roland Barthes is the first epigraph in Andy Merrifield's slim volume The Politics of Encounter. The size of this book may be deceptive, for it is immense-perhaps at points too much so-in terms of the content and concepts it offers. This dialectic of liking and disliking, of love and hate is a starting and motivating point of reference for Merrifield, who insists that thinking-and thinking hard-about the urban condition comes from loving and hating cities simultaneously. Being a dedicated, albeit non-orthodox, Marxist, he attempts to re-articulate what is at stake in thinking about cities politically, humbly acknowledging that it is not an easy task, but nevertheless perhaps a necessary one.

Merrifield's intent is to address two major themes. The first goal is to account for a historical and theoretical turn from the cities to urban society and, eventually, to a planetary urbanization. The shift was already articulated by the "godfather" of urban studies, Henry Lefebvre, over four decades ago. However, Merrifield's ambition goes beyond a mere tracing back of Lefebvre's thought, instead taking Lefebvre beyond Lefebvre. In order to do that, Merrifield puts to use a wide array of tools, from the philosophy of Spinoza, Marx, and Althusser to literary examples from Joyce, Berger, and the science fiction of Asimov, among others. The goal is to arrive at a future-oriented, experimental ontology of urban immanence via the concept of the encounter.

Merrifield's second major task is to test "the right to city" concept. Originally coined by Lefebvre but today most arduously defended by David Harvey, this phrase has outlived its political and analytical utility, argues Merrifield. In a rather quick manner he dismisses "rights" discourse as limited and ineffective, unable to solve the contradictions through formalistic consensus building which cannot (and perhaps should not) be achieved. The second problem is the "city" itself. The city no longer serves analytical purposes: "distinctions between the political and the economic; between urban and rural. And between form and content, conflict and consent, politics and technocracy have lost specific gravity, have lost their clarity of meaning" (129). Instead it is planetary urbanization ("one-world cell-form") that has collapsed all previous boundaries, making the city into a distinct and bounded phenomenon. What is new is not only the scale of urbanization but also new 
technologies which accelerate urban consciousness. Merrifield is sympathetic to synthetic models, where virtual and physical spaces shape each other, allowing for unique opportunities of new encounters. The struggles are no longer about the cities, and they do not necessarily take place exclusively in the cities. Radical politics need to move beyond something so seemingly narrow and at the same time too abstract, such as "the right to the city". Planetary urbanization, therefore, is a broader term in which it is possible to pursue a politics of encounter: identifying affinities, commonalities, and solidarities. "[T]he urban isn't a point fixed in absolute space" (34).

The strength of the book lies in taking risks. Clearly, there will be those in the camp of Marx-sympathizers who will find this book diluting the structural analysis of capitalism (globalization, neoliberalism-you name it) and putting forth well-rehearsed (if evidently ineffective) routes of placing hope in certain revolutionary agents. Alternately, those who, broadly speaking, could be considered Deleuze-sympathizers will also find shortcomings in the somewhat too shallow application of conceptual vocabulary that permeates this book. But as if anticipating this critique, Merrfield acknowledges that his book is first of all a book of ideasworking through hypotheses and unleashing the imagination. It is book that intends to try out new ideas, rework concepts to fit new realities, and abandon them if they are no longer useful. The affinity should be placed-he seems to be suggesting-not in philosophical schools or political movements, but in productive encounters that are willing not only to address negative effects of capitalist urbanization but also positively create present and future scenarios and practices, or, Joycean situations of Here Comes Everybody.

Merrifield, not incidentally, calls for abandoning forms of nostalgia that treat cities of yesteryear as models to return to. Instead, he embraces science fiction, virtuality, and immanentist urbanization not as something positive in itself but as an enlarged field of action and play. The recent examples from Arab Spring to Occupy Movement and Spanish Indignados are treated favorably without making them into the ultimate frontier of what is possible, of the potentiality of present conditions. Thus the role of the virtual world should not be discounted for it is rich with possibilities to ignite wild fires across the globe-to connect various struggles, to mobilize instantly, to inspire. Merrifield does not repeat the oft-rendered critiques of these movements as not demanding anything in particular, as being too horizontal, too spontaneous, and without clear political agenda. He suggests that current and future struggles for urban commons need to invent affective forms of solidarity. These are "revolutionary rehearsals" consciously evasive of old forms of being political (party, state, rights, etc.). They are rehearsing new forms of 
affective sociality and widening the scope of political imagination. If anything it is an illustration of Deleuzean becoming-becoming through encounters with bodies, ideas, spaces. Becoming space. After these encounters nothing stays the same, Merrifield wishes to suggest.

Is the book, in the end, convincing? It has its shortcomings, no doubt. It tries to do perhaps too many things. But it is an honest and admirable effort in terms of what it promises to deliver. It is not a scientific treatise, a manifesto, or a collection of petty arguments and cross-references. It should be seen as an exercise, a conversation starter, a provocation that passionately urges, as Deleuze used to, to search for what works, to go beyond the world as it is towards the potentialities. Merrifield's point is that even if it is possible to apply Marx's insights into the nature of political economy today and be absolutely correct, it is not at all helpful to apply worn out Marxist repertoire in terms of action. Merrifield's little book, if anything, expands the repertoire of potential ways of thinking and doing in a rudimentary but imaginative form.

Reviewed by Arnoldas Stramskas 


\section{ELECTIONS TO THE EUROPEAN PARLIAMENT AS A CHALLENGE fOR} DEMOCRACY, EUROPEAN INTEGRATION AND DEMOCRACY SERIES VOL. 2 (2013). EDS. ELŻBIETA KUŻELEWSKA AND DARIUSZ KLOZA. OFICYNA WYDAWNICZA ASPRA-JR: WARSZAWA AND BIAKYSTOK, 2013.

Prof. Jerzy Buzek, a former prime minister of Poland and Member of European Parliament, opens the discussion with essential and somewhat rhetoric questions such as "does the Parliament change something anyones life?" suggesting that it all depends on mentality and stating that the European Union is not "them" but "us". Is that a dream or reality? It seems that the current book clearly demonstrates that the scene is not black and white - there are many aspects to consider, several options to discuss, lessons to learn.

The weighty book is written in the crucial field and defines the area where countless amount of European scholars have been trying to find a new political perspective for the European Union that would, at the same time, be legitimization of a modus operandi for new Europe. Elections to the European Parliament is a tool for democratic perspective - as the authors of the volume say "a challenge for democracy". That is also a topic of reducing tensions within multilevel governance of Europe. As the European Union moves towards "an ever closer Union", it widens its area of competence and thus encroaches more and more on national competencies, the issue of potential conflicts between the European and national legal orders - a thorny issue already from the start of European integration becomes more urgent.

Although the Community legislator and, much more so, the Community judge tried to solve the issue already in the 1960s, as the Union becomes more invasive into all aspects of national life - from free movement and education to civil liberties and security issues - such tensions become more probable and, in particular, start impinging upon fundamental and even constitutional provisions of member states' legal order. These tensions can no longer be solved by merely applying the principle of the supremacy of EU law, since they touch upon essential constitutional elements of democratic states. ${ }^{1}$

The book is easy to follow by its structure: divided into three parts, it rolls off the analysis of the institution per se, voting systems in selected member states and voting systems in a comparative perspective. First part focuses on the questions that, most likely are in the thoughts of thousands of Europeans, namely the method of elections and the party system of the European Parliament. Italian

\footnotetext{
${ }^{1}$ See Tanel Kerikmäe, Katrin Nyman-Metcalf, Ioannis Papageorgiou, "Is this really what I voted for? Legitimacy of European integration", Baltic Journal of Law \& Politics 6:1 (2013): 45.
} 
contributor Davide Denti indicates that European Party groups are vital and comparable with national parties by their organization, cohesion, stability. The author still finds that "the European party groups have to overcome the challenges of sub-dominance by national parties".

Elena Cincea, contributor from the EU member state with so far very low voter turnout, raises the hypothesis by which the design of the election system could reduce the democratic deficit and aleniation of European citizen from the decision-making process. Other authors are making interesting insight to the gender quota issue and the concept of representation of EU citizen in general. It seems that for the political perspective of the $\mathrm{EU}$, it is unavoidable and relevant to find a dialogue between national and supranational levels. In the context of becoming "citizens Europe", there must be a common understanding of legal framework among member states and EU institutions, to avoid or reduce protectionist elitism and non-equality of members. It is not an easy task and statistics, visions and comparative analysis are not sufficient to receive a "big picture" and understand why the things are as they are. Therefore, I found exciting to read the chapter of Frantciszek Strzyczkowski, a young scholar from Lódź University who opens the eyes of a reader to the theories that influence the essence of the European Parliament, namely rational choice theory and sociological institutionalism.

The second part of the book analyses the voting systems to the European Parliament in selected member states such as Belgium, Czech, Spain, Greece, France, Malta Poland, Sweden and United Kingdom. Researchers point out the reasons of declined voter turnout, namely democratic deficit of the EU in general, complexity and sometimes non-transparency of the decision making process (legitimacy of the European Parliament), ambiguity in relation of future enlargements. There are also explicit country-specific problems related to the electoral systems, domestic policies and how the national parties have been reflecting Europe in their campaigns. For example, Greek author, Georgia Christina Kosmidou points out the need for national parties "to clarify and make their affiliations to European Parties. La Politique Francaise is described by Bernhard Kitous (see the figure 1 and the following explanation in the book).

Another reason is the historical background. As Polish author Andrzej Jackiewicz points out, the low voter turnout is typical to the post-communist countries. Certainly, it is educative to read the analysis of Bogusia Puchalska from Lancashire Law School. United Kingdom has (again, after the last thematical speech of Mr. Cameron following the relative failure in adopting the EU budget) become the symbol of euroscepticism, the author makes good overview of the sources of that 
scepticism referring to the statements of political parties and concluding that in United Kingdom, the debate has always remained the same concentrating on souvereignty and immigration. Identifying him- or herself as an European depends highly on the education. Interestingly, the British author makes reference to the biased educational system that may "indoctrinate" children before they become part of the electorate.

The third part of the book deals with the comparative perspective and starts with the analysis of e-voting. By two authors from Bialystok, Elźbieta Kuźelewska and Izabela Kraśnicka, electronic voting is seen as a "rescue tool" when facing the disharmony in member states electoral systems. Here, the question, discussed by contributors is, what legal basis should be used. Not-so-well functioning American and well-functioning Estonian e-voting systems are described and reasons for their effectiveness rates are reflected. However, in EU scale, authors are in opinion that common approach through the e-voting system is "rather wishful thinking", although possible in the longer term. Last paper relates to two former Yugoslavian republics: Serbia and Montenegro - in both cases the European integration processes visibly influence domestic political atmosphere. The author, Marko Babić, uses the European socialization theory as a basis in screening both countries political landscape.

The total impression of the book is great - it is a comprehensive set of publications that are logically bound, although the methods and aims of the authors vary. The keypoint of the book is to seek for commonalities in Member States and analyse the emerging archidecture of inclusive democracy in the European Union. There are still many obstacles for it. As the German Constitutional Court pointed out in its 2009 ruling on the EU Lisbon Treaty, the German Constitution is one example of how the understanding of sovereignty progresses and changes with time. That is why the common ground for empowering EU - citizen relationship must be found.

Problems with constitutional treaty, dissensions with the new competence areas of the European Union, post-crisis rescue methods such as European Stabilization Mechanism (ESM), still not sufficiently interpreted Charter of Fundamental Rights have been and are signs that rule of law is needed if there are crossroads towards EU further developments. The book's main idea supports the statement of Anni Podimata, vice-president of the European Parliament who recently stressed: "The only way to legitimize and influence EU decision-making is through the European Parliament". The new elections of the European Parliament are knocking on the door. I sincerely hope that this book helps scholars, politicians and European citizens to understand the neccessity to research and analyse 
political advantages of empowering European Parliament as the medium of European vox populi.

Citizen's voice should not be ignored when contextualizing member states' positions in Europe. Taking EU as just interstate governance is clearly not sufficient when trying to find support by memberstate citizens for European integration. The reflected in this book useful tool in the process of understanding the fears and positions both a member state and a citizen. The European crisis, although essentially economic, has also been linked with miscommunication between citizens and decision makers. There is insufficient dialogue between a citizen and his/her representative in the EU. The state representatives have EU agenda that often is isolated fom the public opinion. The consolidation of the positions, awareness and open discussion is not always valuated as the basis of the formation of EU related strategies.

I would conclude my review with the words of one of the author, Tomasz Dubowski from Bialystok university: "the specificy of EU law justifies the tendency towards strenghtening the Union's democratic legitimacy as a legislator".

Reviewed by Tanel Kerikmäe 
TOMAS KAVALIAUSKAS. TRANSFORMATIONS IN CENTRAL EUROPE BETWEEN 1989 AND 2012: GEOPOLITICAL, CULTURAL, AND SOCIOECONOMIC SHIFTS. LEXINGTON BOOKS. 2012.

I absolutely agree with the book's back-jacket blurb by Maria Mälksoo (University of Tartu), which contends that Tomas Kavaliauskas' Transformations in Central Europe Between 1989 and 2012 "makes an unusual and refreshing, even romantic, piece of scholarship". While reading this monograph, which consists of twelve interlinked essays, I kept reminiscing about the year-which the author calls annus mirabilis-of the "Baltic Way" when thousands of people unified as one political body for liberation from the communist Soviet Union. Despite this review's limited length, there are several themes worth lingering on; I will limit myself to only several. But first for an introduction of contents: 1. Defining Central Europe as a Postcommunist Region; 2. Positive and Negative Freedom in Central Europe before and after 1989; 3. Virtual and Real Freedom in Central Europe; 4. The Complete and Incomplete Transition in Central Europe; 5. Fluctuating Socioeconomics and Postsocialist Inverted Morals; 6. The Salvation of the Two Europes in 1968 from the Perspective of 1989; 7. Vilnius 10 Group - Geopolitical Emancipation or a Lost Opportunity for Angelic Moral Politics?; 8. The Demiurge of the EU and Central Europe; 9. Different Meanings Applied to May 9th Victory Day in WWII: Russian and Baltic Perspectives after 1989; 10. Social and Political Meaning of Light in Central Europe before and after 1989; 11. Communist Nostalgia as Extrapolation of the Past into the Present; 12. Katyń Does Not Happen Twice. Behind these intriguing titles lie sophisticated reflections indeed. One may disagree with some of them, but one cannot turn away in apathy, especially those who themselves were witnesses to the described transformations.

If in two words I had to characterize the essence and the nature of the changes as they are described in Kavaliauskas' book, those words would be "liberation" and "complexity". The author wonderfully avoids primitive simplifications, which are illustrated in citations of other scholars. Such quotations one may expect to overhear in a conversation of housewives, but not of scholars of transitology. For instance, the author categorically rejects the opinion according to which Slovenian nationalism is supposedly "European", whereas Croatian "and especially Serbian nationalism" is identified "as barbaric, as non-European". ${ }^{2}$ Additionally, writing about the problems of national minorities in Latvia and Estonia, the author manages to rise above non-critical and self-satisfactory "Baltic

2 Tomas Kavaliauskas, Transformations in Central Europe between 1989 and 2012: Geopolitical, Cultural, and Socioeconomic Shifts (Lexington Books, 2012), p. 33-34. 
solidarity" by acknowledging that the catalyst of tensions are not only Russian speakers, but also Latvian and Estonian "radical nationalists". ${ }^{3}$ When the author analyzes the controversial so-called "Vilnius 10" that supported the U.S. war in Iraq, the conclusion is that "geopolitical emancipation in the region was achieved, the voice of the Vilnius 10 Group was heard, pro-American identity was fortified, but at the expense of the tradition of moral politics, the politics of conscience, and the politics of living in the truth". ${ }^{4}$ The book also rejects the explanation of the hardships of the post-communist transformations (that was and partially still is popular) in the categories of the "Soviet heritage" as well as homo sovieticus. ${ }^{5}$ Moreover, the author also questions the optimistic-linear interpretation of postcommunist transformations (the cornerstone date 2004 when the most of Central European countries joined the EU) "as progress in the old fashion of the Enlightenment". He raises the following question: "(...) for whom is democratic pluralism and socioeconomic success - for the few oligarchs and political elite or for the regular citizens?" 6 The reason for this question is that the author is unwilling to nod his head in approval of the view of Zenonas Norkus, who believes in successful post-communist transformations. For Norkus it suffices to accept the fact that the transition from communism to liberal democracy and market economy did indeed happen ${ }^{7}$; however, for Kavaliauskas it is insufficient, because he calls attention to the problems of minority rights and geopolitical shifts. ${ }^{8}$ Lots of attention is given to the identity of Central Europe, i.e. the paradoxical identity of Central Europe, and to the problems of the identity of the EU itself. ${ }^{9}$

But, it seems that in painting a complex picture of the liberation of Central Europe the specifics of Lithuanian liberation could have been more highlighted. When the author discusses different experiences of 1989 in Central Europe and in the Balkans, he writes: "The very 1989 in this Balkan region had a different meaning than in Central Europe. If in 1989 Central Europe celebrated the fall of the Berlin Wall witnessing deconstruction of the oppressor, USSR, so in ex-Yugoslavia annus mirabilis signifies the rise of the oppressor, Serbia". ${ }^{10}$ After all, the Serbs ended up being losers of the former Yugoslavia wars. And I speak about "the specifics of Lithuanian liberation" in the same (hopefully not meaningless) context, raising the following question: Who and how much was gained (or lost) because of

\footnotetext{
${ }^{3}$ Ibid., p. 55-57.

${ }^{4}$ Ibid., p. 122.

${ }^{5}$ Ibid., p. 39.

${ }^{6}$ Ibid., p. 53.

7 Zenonas Norkus, Kokia demokratija, koks kapitalizmas? Pokomunistine transformacija Lietuvoje lyginamosios istorinès sociologijos požiūriu (Which Democracy? Which Capitalism? Post-Communist Transformation in Lithuania from the Viewpoint of Comparative Historical Sociology) (Vilnius: Vilniaus universiteto leidykla, 2008), p. 345 [in Lithuanian].

8 Tomas Kavaliauskas, supra note 2, p. 61-68.

${ }^{9}$ Ibid., p. 1-9, 32, 126-134.

10 Ibid., p. 25-26.
} 
the collapse of communism? Lithuanians, Latvians, and Estonians are the only ones in the entire post-communist space who reestablished statehood that existed during the interwar and was annexed by communism. In this sense of independence restoration, they gained the most. But paradoxically that gain of the Baltic States also hides dangers. The Baltic States did win the most of all post-communist countries not erased from the political map of communist countries and which had a weak memory of their independent existence as a state due to their longer experience of the Soviet empire. That is why independence in the Baltic States was celebrated more enthusiastically than in the former Yugoslavia and Transcaucasia, where independence was accompanied with enormous bloodshed. And the emotional joy of the Baltic States also surpassed Russia, which liberated itself by losing its own empire and submitting to the symbiosis of very questionable quality of democracy and oligarchic capitalism. Lithuania gained even more than Latvia and Estonia, because the former for the first time in its history united Vilnius and Klaipeda in its body of a political State, whereas the latter lost some of the districts that in 1940 had bordered Russia and received the "gift" of the highly populated Russian speaking communities.

After independence in Lithuania a specific public-political discourse was formed that blocked Lithuania from formulating a serious social justice strategy (which was considered to be a relic of the Soviet nostalgia), on the one hand, and which on the other hand did not allow for the emergence of a critical self-analysis of the new sociopolitical and socioeconomic condition(s) in which the State found itself after liberation from communism. This public-political discourse on capitalist evil heralded the idea that it is a necessary price for freedom in the period of transition. Not coincidentally we had to wait quite a long time for deeper and more critical reflections of the reality of Lithuanian capitalism. Only after twenty years of independence did fundamental studies of postcommunist transformation emerge, such as Zenonas Norkus' work Which democracy? Which capitalism, and Postmodern Capitalism by Vytautas Rubavičius. Yes, indeed, let us ask what kind of capitalism formed in Lithuania and Central as well as Eastern Europe after communism. The book that is being reviewed here tells us that "wild capitalism in the early 1990s (...) in Lithuania and especially in Russia was possible thanks to the lack of law restrictions as well as a corrupt judicial system". ${ }^{11}$ Before coming back to a more precise definition of "wild capitalism", let us briefly linger on another issue.

After once again underlining the complexity of the vector of spiritual liberation in Central Europe-"liberal spirit for salvation was mixed with nationalist sentiment

${ }^{11}$ Ibid., p. 84. 
and religious conservatism"12-Kavaliauskas, in his attempt to explain the "success story" of Central European post-communist transformations, gives preference to one component: "The kernel of liberalism inside ethnocentric nationalism might be the answer to the question why Central Europe developed faster than Eastern Europe and why Central Europe avoided a war while ex-Yugoslavia did not." ${ }^{13}$ It is important to call attention to the intricate and almost labyrinthine relationship between "liberal nationalism", to which Kavaliauskas evidently shows his preference in contrast to destructive the "radical nationalism" of the Serbs and Croats, ${ }^{14}$ which in its own turn seems to be the expression of excessive and aggressive "ethnocentric nationalism". Let us briefly acknowledge the importance of Vytautas Kavolis in the Lithuanian intellectual panorama-Kavolis being, in my assessment, one of the most distinguished representatives of Lithuanian "liberal nationalism". Kavaliauskas emphasizes that "in Lithuania the most prominent liberals do not have a unanimous view regarding Lithuanian ethnicity". Contrary to the poet and former dissident Tomas Venclova, who "recently made a statement that all Lithuanians are Poles, providing his logic and examples of Lithuanian identity within the Polish linguistic framework", Vytautas Kavolis, renowned scholar of world civilizations and sociologist, was convinced that "the maturity of Lithuanian consciousness reached its glorious peak purifying the Lithuanian language from Polish and establishing a Lithuanian worldview". Because of Kavolis' theory, which "not only reconciles liberalism and nationalism, but shows that these two can be compatible when civilizational polilogue among the nations includes both the local experience and the experience of the Other", Kavaliauskas suggests the term "ethnocosmopolitanism"15. Having briefly acknowledged Kavolis' role, let us return to annus mirabilis by asking: Whose spirit hovered over the crowds of thousands of people in 1989? Was it not hovering in the spirit of romantics such as Maironis and Juozas Naujalis, Bernardas Brazdžionis, and Justinas Marcinkevičius with his theater plays "Mindaugas", "Mažvydas" and "The Cathedral"? ${ }^{15}$ Did "the kernel of liberalism inside ethnocentric nationalism" determine peaceful gatherings of the Lithuanian crowds? We may possibly explain it in that way as well, but I would prefer to interpret the nationalism of annus mirabilis - at least in the case of Lithuania simply as "romantic nationalism". In the sphere of music that would be such Central European national romantics as Frédéric Chopin, Ferenz Liszt, and Antonin Dvořák. But how and why this romantic-ethnocentric nationalism converts into destructive radical nationalism is a difficult question. I think that Kavaliauskas overemphasizes

\footnotetext{
12 Ibid., p. 29-30.

13 Ibid., p. 32.

${ }^{14}$ Ibid., p. 36.

${ }^{15}$ Ibid., p. 41-42.
} 
the positive role of "liberal nationalism" and for that reason I am on the side of Jacques Rupnik and Martin Palouš, with whom Kavaliauskas argues on this question. Rupnik writes: "the major difference between Central and Southeast European is not that the former are more tolerant and pluralistic, but that their 'ethnic cleansing' was completed half a century ago, whereas in the Balkans the process of 'homogenous' nation-state is still under way $(\ldots)^{\prime \prime} .^{16}$ Of course, categorically one cannot say that "ethnic cleansing was completed in Central and Southeast Europe half a century ago", because large ethnic Hungarian populations do exist in Romania and Slovakia. However, we cannot ignore the fact that the consequence of the Second World War is not only the genocide of Jews and Roma people, but also coercive resettlement of millions of regional populations-first of all Germans-that were allowed to create homogenous Polish and Czech nations. As a matter of fact, a homogenous Vilnius as well as Klaipeda is also the result of World War II. We may also recall Turkey with its Kurdish and Armenian minority problems. If the "Kurdish problem" is considered along the lines and categories of "separatism" and "fight against terrorism", so the "Armenian problem" exists under a different category-the acknowledgment of Armenian genocide, which Turkey is reluctant to acknowledge, but thanks to which today Turkey no longer has Armenian minority issues. However, we should not disregard Palouš's interpretation, according to which, the reason for the war in Yugoslavia was "the reemergence of ethnicity that was suppressed by communist ideology and kept in a 'frozen' state during the four decades of the cold war". ${ }^{17}$ Russian Eurasian intellectuals, as early as the 1920s, wrote about communist ideology as "unifying all USSR nations into one single statehood being a factor that opposes the influences of national-separatism." At the same time the Eurasian intellectuals foresaw that "the idea of proletarian dictatorship, promotion of proletarian solidarity, and instigation of class oriented hatred at the end may become insufficient means against the nationalistic and separatist striving of the nations of the USSR." ${ }^{18}$ Thus, the answer to the question of why "nationalistic and separatist striving of the nations of the USSR" did not deliver (at least in the European part of the USSR) the nightmare of Yugoslavian war after 1989 should not rely only on the factor of "liberal nationalism". Different histories of the European part of the postcommunist USSR and Yugoslavia are determined by different configurations of memory due to World War II. Differently than the largest Yugoslav nations (Serbs and Croats), the absolute majority of Russians, Ukrainians and Byelorussians fought against a

\footnotetext{
16 Quoted in Tomas Kavaliauskas, supra note 2, p. 34.

17 Ibid., p. 35.

18 Nikolai Trubeckoi, Nasledie Chingishana (The Legacy of Genghis Khan) (Moskva: Agraf, 1999), p. 498499 [in Russian].
} 
common enemy: national-socialist Germany. The difference also has to do with the USSR as having the status of a nuclear state and the characteristics of individual Serb and Croat leaders.

When Kavaliauskas writes about socioeconomic transformations and analyzes the truly revolutionary "turning vices and virtues upside down"19 that happened in the postcommunist Eastern and Central Europe, we may have in the mind the peaceful nature of the transition-quite different from classical (or "modern") political revolutions-and, consequently, we may assume that this "postmodern" transformation in the societies took place on the platform of some sort of social consensus of fundamental ideological paradigms as well as their shifts. True, it is a self-evident fact that the Eastern and Central European countries that participated in the postcommunist transformations did change. But it is also self-evident that there is no consensus as to how to value these changes. It is an eloquent fact that the four (of five) philosophers still living from the group of Sajūdis-Bronislovas Genzelis, Romualdas Ozolas, Vytautas Radžvilas, and Arvydas Juozaitis-today assess Lithuania's condition quite critically. There is no self-evident answer to the following question: to what extent did various social groups understand the content of the above-mentioned consensus of fundamental ideological paradigm shifts? "We did not fight for the kind of Lithuania that we have today"-this painful claim testifies that back in 1989 there was a lack of understanding of the content of ideological paradigms and their shifts in the upcoming post-communist period. People did not understand what transformations were awaiting. It is difficult to disagree with Kavaliauskas' assertion that "nationalistic movements based on ethnicity and Christian respect for the individual's salvation went hand in hand with the goals of negative freedom from oppression and positive freedom to human rights". ${ }^{20}$ However, as Kavaliauskas rightly adds, although negative freedom from communist oppression was achieved, the positive freedom (in the sense of Isaiah Berlin to whom Kavaliauskas refers) in the socioeconomic dimension remains virtual, ephemeral, intangible. Thus, even if we do not want to accept the overly categorical statement by Norkus that "for many (if not for the majority of) Lithuanians the ideal was Soviet socialism with national colors" ${ }^{21}$ still we must recall that the striving for larger social justice (one of the declared goals of Sajūdis was namely "a fight against privileges") was understood as an integral part of

\footnotetext{
19 Tomas Kavaliauskas, supra note 2, p. 84-85.

20 Ibid., p. 30.

21 Zenonas Norkus, "Sparčios sèkmingos pokomunistinès transformacijos ir jos nesèkmès 'dèsniai': daugiareikšmiu kintamuju kokybinè lyginamoji analizé" (The 'Laws' of Rapid Successful Postcommunist Transformation and its Failure: Multi-Value Qualitative Comparative Analysis), Politologija 4 (60) (2010): 38 [in Lithuanian].
} 
positive freedom. Unfortunately, no one foresaw room for social justice in the paradigm of neoliberalism that arrived in place of communism.

"Although during the liberation from the Soviet occupation the hopes for national state building and fortification were fostered, the processes of globalization and the neoliberal economic reconstruction soon dispersed such hopes", ${ }^{22}$ writes V. Rubavičius, author of Postmodern Capitalism. In some pages of his book Kavaliauskas also names postcommunist transformations as "neoliberal". ${ }^{23} \mathrm{He}$ mentions the "Chicago school" and its famous, or rather infamous ideologist Milton Friedman, whose "triple P formula"-"privatization, privatization, privatization"-for the post-communist countries "had just too many cases of devastated lives and swallowed small business. ${ }^{24}$ However, we should bear in mind the wide range of contradictory evaluations of neoliberalism. Marek Skovajsa (Charles University, Prague, Czech Republic) in the forward of Kavaliauskas' book writes the following:

The reintroduction of capitalism and the policies of Neoliberal reform in the region are no longer greeted as a straightforward blessing. On the contrary, there is a growing tendency, not restricted to but conspicuous in the postcommunist countries of Europe, to see in Western-made liberal democracy and capitalism a Trojan horse for yet another form of intrusion into the region by forces that exploit and exhaust rather than foster its vital resources and violate rather than enhance its deepest values and convictions. ${ }^{25}$

Here let us recall the following insight from Kavaliauskas: "It seems that the West wanted to embrace Central Europe as much as the latter wanted to unite with the West, if not more". The term neoliberalism is so elastic as to include accusations of genocide:

Neoliberalism is by nature genocidal (and suicidal) because in order to survive, it has to eat its own tale. In other words, by 'killing' the working class, capitalism is digging its own grave. When the working class is dying, society is dying, which at the end will lead to the death of capitalism itself. (...) The present capitalism regime must be changed in order to become a sustainable one. The capitalist regime must serve at best the basic tenet of liberalism, that the economy must work to the good of the majority, not the vice versa. Otherwise homo economicus could develop into homo homini lupus, and hence rampaging genocidal societies at both local and global levels. ${ }^{26}$

22 Vytautas Rubavičius, Postmodernusis kapitalizmas (Postmodern Capitalism) (Kaunas: Kitos knygos, 2010), p. 226 [in Lithuanian].

${ }^{23}$ Tomas Kavaliauskas, supra note 2, p. 57, 173.

${ }^{24}$ Ibid., p. 94.

25 Marek Skovajsa, "Foreword. Rediscovering Postcommunist Central Europe": xiii; in: Tomas Kavaliauskas, supra note 2 .

${ }^{26}$ Siswo Pramono, "The Genocidal Global Politics and Neoliberalism," Journal of Economic and Social Research 5 (1) (2003): 121, 115. 
But despite this breadth of usage and definition, in my opinion the term "neoliberalism" deserves more frequent usage. Hardly anyone would hold it to be a mere coincidence that in nearly all the Eastern and Central European countries which were hit by neoliberal reforms, there have been sad demographic tendencies for the last twenty five years. Let us not forget that before these reforms demographic curves were rising. Kavaliauskas writes: "a liberal in Central Europe has to ask: what are the premises and historic contexts for the nationalistic position in Hungary and other countries?"27 Perhaps in this historical context the neoliberal European present is not in last place? After all, as David Harvey, author of $A$ Brief History of Neoliberalism, writes:

The reduction of 'freedom' to 'freedom of enterprise' unleashes all those 'negative freedoms' that Polanyi saw as inextricably tied in with positive freedoms. The inevitable response is to reconstruct social solidarities, albeit along different lines-hence the revival of interest in religion and morality, in new forms of associationism (around questions of rights and citizenship, for example) and even the revival of older political forms (fascism, nationalism, localism, and the like). Neoliberalism in its pure form has always threatened to conjure up its own nemesis in varieties of authoritarian populism and nationalism. ${ }^{28}$

It is hard to say whether the dialogue between the Baltic States and Russia over conflicting historic interpretations would be more fruitful if in postcommunist Russia there were a more socially just society. I contend that Russia created the most socially unjust society in the postcommunist area because of drastic neoliberal reforms conducted by the administration of Boris Yeltsin (actively supported by the West). All that also contributed to the situation in which "even common space for safe competing interpretations is in question". ${ }^{29}$ After all, when quite a number of Russians justify Joseph Stalin or regard their communist past in positive terms, they do it not so much because of love for the dictator or the communist limited and often degrading social conditions, but because of detestation for today's social inequality and oligarchic Gazprom's capitalism for the few lucky ones, while condemning the rest of the society for inhumane social conditions without any choice for the politically alternative voting.

But it is possible that the avoidance of frequent usage of the term "neoliberalism"-associated with the negative side of the socioeconomics-reflects Kavaliauskas' more optimistic personal view towards transformations in Central Europe-at least more optimistic than what I hold; therefore, this review could be

\footnotetext{
27 Tomas Kavaliauskas, supra note 2, p. 67.

28 David Harvey, A Brief History of Neoliberalism (New York\&Oxford: University Press Inc., 2007), p. 8081

${ }^{29}$ Tomas Kavaliauskas, supra note 2, p. 154.
} 
meaningfully completed with the last metaphorical words from chapter 10, which seemingly carry the worldview of the author himself:

In conclusion would be just to say that the consumerist light continues to shine twenty years after postcommunist transition, but that light is polluted, no longer as romantic. Just like Nika Radic, the Croatian artist working in Berlin, showed a photo in which the light coming out of the projector in the cinema was sort of yellowish and contaminated because that was produced in the 1950s when smoking was allowed in cinemas-the light in the dark room enlightened the hovering smoke of cigarettes. Similarly, the social and political light of 1989 shines in 2012 as well, but it is polluted or contaminated by social injustices, inequalities, social stratifications, and greed. Perhaps there is no pure light as such even on the empirical level. (... ) When it comes to a metaphoric treatment of light, the purity of the Platonic sunshine is not for everyday reality. In the case of transitional postcommunist experience, it is more meaningful to search for fragmented glimpses of the unveiled truth. ${ }^{30}$

Reviewed by Andrius Martinkus

${ }^{30}$ Ibid., p. 165. 